\title{
Articulations of the city as a gendered construct ${ }^{1}$
}

Since the onset of mechanisation and industrialisation from the beginning of the nineteenth century, machine culture has developed into the fibre of the global world. Today the contemporary city's ontology manifests as a condition of transitivity evident in the mobility of communication networks and high-volume traffic on highways. The effect of this decidedly techno-scientific environment on the behaviour and emotions of people is a topic that, since the commencement of such technologisation, has received much attention in socio-cultural theories, literature and the visual arts.

The notion of the city dweller or stroller is found in several literary and visual texts, as well as in cultural theories, and the concept has been articulated in various guises. In early travel writing, the city in all its artificial density, complexity and spectacularity was often romanticised ${ }^{2}$ and associated with notions of spectacle and paradise. Evidenced in images of and writings on Arcadia, Utopia, 'Elsewhere' and the 'Other World', the idea of the city as pleasurable spectacle has been articulated in works such as the famous travelogue by Jonathan Swift, Gulliver's travels (1726). In Chapter 2, after having been washed up on the island of Lilliput, Lemuel Gulliver opens his eyes and sees: 'The Country round [appearing] like a continued Garden; and the inclosed Fields, which were generally Forty Foot square, resembled so many Beds of Flowers. These Fields were intermingled with Woods of half a Stang, and the tallest Trees, as I could judge, appeared to be seven Foot high. I viewed the Town on my left Hand, which looked like the painted Scene of a City in a Theatre' (Swift 1726:29).

Similarly, in 1778, British travel author William Coxe (Briganti 1969:227) wrote: 'As I walked about this metropolis I was filled with astonishment upon reflecting, that ... the views upon the banks of the Neva exhibit the most grand and lively scenes I have ever beheld ... it is also deep, rapid, and as transparent as crystal; and its banks are lined on each side with a continued range of handsome buildings'. 
In this article, a closer look is taken at the concepts of the passant and the flâneur as articulated within the context of urban spectacle and artifice.

\section{The archetypal city dweller}

An exploration of the relationship between human beings and machine culture as artifice is already found in French materialism between 1740 and 1850 in texts such as L'homme machine (1748) of Julian Offray de La Mettrie (actually a medical doctor). In these texts, an explicit erotic basis for mechanisation, urbanisation and technology was firmly established and the visual form of mechanical devices such as clocks, aircraft, cars, engines, locomotives, pianos, coffee grinders and sewing machines became sexualised ${ }^{3}$. The mechanics of such objects were seen to be a reflection of the cosmic order of perfection, the universe as clockwork and human beings as machines (de La Mettrie in Berlin 1956: 269, Woesler de Panafieu 1984:130). De La Mettrie altered the postulation of the Renaissance philosopher and mathematician, René Descartes, that human beings are like machines to the explicit claim that they are machines (Woesler de Panafieu 1984: 130).

As part of this gendered human-machine relationship, the idea of the archetypal city dweller became prominent in the nineteenth-century literary and visual texts. Fundamental to the understanding of the concept, are the notions of mobility and transitivity. According to William Sharpe ${ }^{4}$ (1990:1), the archetypal city dweller is always on the move. In several of his poems, the nineteenthcentury poet Charles Baudelaire expounded the idea of the passant as a male (mostly the poet himself) roving the city and experiencing feelings of worship and love for the city as woman. Baudelaire expressed the idea of the 'holy prostitution' in the 'chaos of living cities' (Sharpe 1990:40) and presented the city as a phantasmal site of sexual ecstasy where the poet and the crowd or the unknown passer-by, merge. In $A$ une passante in the 1861 edition of Les Fleurs du Mal, for instance, he describes a woman, dressed in black, who emerges from the dark and vanishes again, and the male poet who instantly falls in love with her.

In the figure of the passing woman, the 'mobile image of unfulfilled desire' (Sharpe 1990:40) observed and followed by the male passant, sexuality and 
textuality ${ }^{5}$ converge and transitivity is conflated with notions of pursuit ${ }^{6}$. This idea is already encountered in alchemical texts such as Michael Maier's Emblema XLII from the Atalanta Fugiens (1617), Figure 1, as well as in William Blake's "London", Songs of innocence and of experience of 1794, containing images of the male stroller pursuing the female passant. The quest of woman could be decoded into many different metaphors: she could represent a desire for a lost mother/fatherland, a Romantic or erotic unknown, truth ${ }^{7}$, the muses or a sublime. Irrespective of such interpretations, the most fundamental characteristic of the urban passant is that of mobility, alternatively construed as transitivity. Sharpe (1990:2) confirms this argument remarking that: 'Like the story of Cain, Blake's [London (1793)] ... shows that mobility and marking are interdependent features of both cities and texts. Men strive to control their world through mapping, street building, and sign writing, but these avatars of Cain's mark instead produce only further signs, further wandering and marking'.

The Baudelairian idea of the passant is reflected in twentieth-century cultural theorist Walter Benjamin's concept of the flậneur, correspondingly male. I nitially encountered in his 1924 tale of Naples, the notion of the flậneur was a response to the city's passion for improvisation, ironies and theatricalities (Amin and Thrift 2002: 10). Benjamin (Bertens 1995:213) writes:

In this aesthetized commodity world the department stores, arcades, trams, trains, streets and the fabric of buildings and the goods on display, as well as the people who stroll through these spaces, summon up half-forgotten dreams as the curiosity and memory of the stroller is fed by the ever-changing landscape in which objects appear divorced from their context and subject to mysterious connections which are read on the surface of things. The everyday life of big cities becomes aestheticized.

Since the second half of the twentieth century, the notion of the gazing stroller has become less gender-specific and more diversely applied. Guy Debord, for instance, the founder of the Situationistes Internationale, developed the term 'psychogeography' in his 1957 article, 'The naked city', which entailed a study of the impact of zones in the city on its inhabitants (Coelewij 2002:5). In The electronic eye: The rise of surveillance society (1994), David Lyon of Queen's University, Ontario, argues that industrial communities have become societies of surveillance, a theory that echoes Benjamin's idea of the flậneur. Similar to the 
notions of the stroller, the flậneur and the passant, theorist Michael Heim (2001:71) interprets human beings' intimate acts of surveillance and 'strolling' through cyberspace, virtuality and artifice as forms of erotic pursuit and desire.

The Berlin-based German artist, Franz Ackermann's aerial view of Amsterdam (Figure 2) is more than a surveillance of the physical space of the city: it entails a mental psychogeographical map and a subjective, non-neutral rendering of sectors, routes and experiences. Reference is made to 'travel' in hyperspace, to Internet navigation strongly premised in the Internet user's subjective preferences and subjectivity. Amsterdam Digital City (1994), Figure 3, was a Web production that was produced by Dutch artist Walter van der Cruijsen, also Berlin-based. On the Internet the artist surveyed the city in cyberspace via webcam technologies, in particular inspecting squatting practices in abandoned city spaces ${ }^{8}$. Although both Ackermann and Van der Cruijsen are male artists and conceptually explore the city in the attempt to penetrate its structure and logic within a male mindset, the notions of surveillance and navigation in virtual space are not gender specific in contemporary culture.

In Iglesias' vegetation rooms, Figure 4, nature is represented in concrete: dead and lifeless. The male passant passes through the installation in apathetic manner, indifferently observing the hyperreal of recreated foliage and erotic surface texture and cavity. In Figure 5, the futility of pursuit and the meaninglessness of replication are rendered in an example of Cuban artist Francis Alÿs' many dystopian anti-passant depictions of the Doppelgänger. Alÿs describes this process as follows: 'When arriving in ... Havana (new city), wander, looking for someone who could be you. If the meeting happens, walk beside your doppelgänger until your pace adjusts to his/hers. If not, repeat the quest in ... (next city)' (Urban Myth 2001:46-49).

To the viewer the idiosyncratic strollers seem at once familiar and unfamiliar due to the elements of surprise and novelty (unfamiliarity) often encountered in the post-modern (familiar) city. They seem to be purposefully on their way somewhere and yet simultaneously appear to be casual and unimportant persons. One could be looking at scenes (fictional characters) from a film, or the figures could be 'real' people, authentically photographed in the street. In Alÿs' work, the idea is expressed that in the metropolis there is multiple duplication 
and that even the urban dwellers are nothing more than Doppelgänger. In addition, the idea of pursuit is articulated and the work becomes a kind of 'following piece', a particular idea explored in several late twentieth-century artworks, such as those of Italian Performance artist, Vito Acconci.

Following philosopher Jean Baudrillard (1996:124), it is in the act of pursuit and the idea of the Doppelgänger, that is, the body or the construct's resemblance to and pursuit of its model, that the eroticism of the act is constituted. The passant and the flậneur thus ensue as 'mobile image[s] of unfulfilled desire' (Sharpe 1990:40).

\section{Gazing at the city}

The city as gendered construct encompasses both sexes: the city as female seductress and passante mesmerising the male stroller or passant roving the city. The afore-mentioned visual and literary texts confirm that it is not only the notion of the mobility of the passant that is at stake here; it is also its gaze ${ }^{9}$. Amin and Thrift (2002:111) view the city as: 'both a focus and a producer of bodily experiences and desires which can touch on each of the senses and combinations thereof in all kinds of unexpected ways .... In many urban utopias sensual impulse is reined in - except for the obsessive visual gaze'.

In Baudelaire's Paysage (1857), the poet gazes at the city from his attic window and sees 'the chimneys, the clock towers, those masts of the city, and the great skies that make one dream of eternity' (Sharpe 1990:41). A hundred years later, the same point of view is encountered in the foggy photographs of Paris of Modernist artist-photographer, Brassaï, once described as the 'the eye of Paris', where the physical boundaries of the city are transcended and the male gaze of the photographer is transfixed on the beauty of the urban architecture, its concealment and ambiguity ${ }^{10}$.

Within the urban context, the gaze can be interpreted as embodying Utopia since the establishment of cities and their architecture from the beginning were related to the ideas of progress and advancement ${ }^{11}$. In his article, 'Bridge to Utopia: The Brücke as Utopian experiment', Reinhold Heller invokes a gendered 
interpretation of Modernist Utopia by arguing that it was 'conceived and generated for and by men, with women serving subsidiary roles as "companions and helpers", in Kirchner's words' (Heller 2001:80). In such a patriarchal mindset endorsing a male dominated order, men are considered as the thinkers, planners and economists of the city, therefore as the machinery, the core of urban industry ${ }^{12}$.

The American urban theorists of the early twentieth century, Modernists such as Lewis Mumford, followed a structural approach to cities in their search for generic and universal traits, and at the same time propagated a Utopian (and male) conception of the city. Viewing the city as an organism (Amin and Thrift 2002:8), they believed that underneath the disorder and clutter of urban life, cities contained an inherent integrity of order and structure, a generic patterning of high-rise buildings, towers, domed structures and highways. Expressionist cityscape and architectural renderings of the early twentieth century, especially those of Die Brücke, Utopian, mythological and paradisiacal images abound, possibly as a response to the evils and horrors of urban overcrowding and Industrialisation ${ }^{13}$. Concurrently, phallic forms representing Utopian perceptions proliferated in Modernist renderings ${ }^{14}$.

Yet, many Modernist works speak of dystopia and alienation rather than of Utopia, such as Ludwig Meidner's Strasse im Wilmersdorf (1913) ${ }^{15}$ and George Grosz's Vorstadt $\left(1915\right.$ - 1916) ${ }^{16}$. In these works the artists' gaze at the city reflect experiences of hostility and alienation. Cultural theorist Andreas Huyssen argues that: 'In our century, the discourse of the end of Utopia is as endemic to the utopian imagination as its visions of the world, other times, or other states of mind' (Huyssen 1995: 85, my emphasis).

I argued elsewhere that: 'Most structuralists, opposed to and critical of utopianism since they blame the problems of modernity on it, display binarism in thinking in their rejection of the idea of history as continuity. The profound disgust with historicism, which occurred during the nineteenth and twentieth centuries, became acute as a result of a disillusionment with the cult of historical 
consciousness accompanied by a scientific worldview' (Dreyer 2001:40, my emphasis).

In T. S. Eliot's dystopian metropolis in Wasteland (1922), the ruins of Western civilisation are depicted comprising perverse personae, sexual dysfunction, social alienation, spiritual despondency, and so on ${ }^{17}$. Eliot conflates sex and city, and develops the notion of the anti-passant, in the form of the blind prophet Tiresias who cannot see or gaze at the city. He is bisexual, an old man with wrinkled breasts, and 'moves through the city like a negative passant, very much an hypocrite lecteur fallen prey to the most insidious vice of all, a timeless Ennui that can never break through to a new version, a new vision' (Sharpe 1990: 107).

The act of gazing at the urban spectacle is conspicuously developed in Vanessa Beecroft's series of performances entailing the staging of nude women. In Show (April 23, 1998), presented at the Guggenheim Museum in SoHo, New York (Figure 6), twenty models with flawless figures posed as lifeless mannequins in a performance of three hours. The performance embodies notions of dystopia and alienation whist simultaneously embracing the ideals of female beauty. Simulating the city as a hype of production and artifice but also as spectacle, the beautiful un- and half-clothed women are objectified and the boundaries of the model as window dummy, virtual Internet image and real woman become blurred. Several other entities become fused: real and artificial; shop and museum; viewer as consumer and viewer as producer of meaning; objectified woman versus empowered woman; and woman as creature of social reality as well as of fiction. Via the means of spectacle and voyeuristic gaze, the women embody the spectacular beauty of the city: they are the objects of desire of the passant, the flậneur and the urban voyeur.

In the work of South African artist Stephen Hobbs, the city of J ohannesburg is the focus of the artist's gaze (Figure 7). The downtown psychopathology is studied in works such as Dusk Till Dusk (1997), a time-lapse piece that records twenty-four hours of the street corner view from Hobbs's bedroom window. In On Interesting Spaces (Figure 8) also of 1997, Hobbs pays homage to Andy Warhol's early video work Man Smoking a Cigar. The two figures in the work are besides Hobbs, South African author and critic Clive Kellner, both dressed in 
suits, leisurely smoking cigars and engaged in concentrated conversation. The work depicts the two men as city dwellers and gazers seemingly at ease with their position of authority, although Hobbs (s.a.) states that: 'I look at the city in a behaviourist kind of way. I'm not interested in the way cities work, but in the way they don't work, in the politics of space and abandonment. Modern cities are organised into grids, but within those grids, there's disorder. It's the phenomenon of the city I try to image'.

The artist articulates an ironic stance of dystopia within Utopia by rendering the city as a fine-tuned system of social, economic and spatial engineering. Similarly, Huyssen (1995:86) identifies such irony by arguing for the 'indestructibility' and the 'irrepressibility' of the Utopian imagination manifesting in the midst of Sixties' cynicism evident in the many end-of-ideology theses that emerged during this time (Dreyer 2001:40).

In Tracy Payne's Coastal resort, Figure 9, the idealised and beautiful female sexual body has collapsed into a pitiful wreckage. The imagery of the disfigured woman and the technological debris of manufacture surrounding her comment on the devastating effects of urban artifice and lifestyle. The work speaks of the flậneurs or passants dystopian gaze at the nude body as a site of debris, metaphoric of the gaze at the dystopian city as site of ruin and disjunction. The dystopian body, mirrored in the dystopian city, according to Baudrillard (1996: 127) has become a desireless 'hyperbody, of a now indifferent and useless sexual function'. There is dissolution of boundaries - of the body, the city and the real - since the artifice of machine culture and the Post-industrial world are at once novelty and clone; that is, at once innovation and model.

Similarly, American biologist Donna Haraway (1991:29) articulates a radical dystopia in that she argues that the Post-industrial cyborg ${ }^{18}$ 'does not expect its father to save it through a restoration of the garden, ... [since it] would not recognize the Garden of Eden; it is not made of mud and cannot dream of returning to dust'. Within the context of the dystopian city, a new mythology of the 'original' or ideal 'home', other than pre-lapsarian (or pre-deluvian) paradise or post-lapsarian Utopia, is created. The new mythical 'home' in the city can be articulated not as a simplistic, mono-narrative or even teleological mythology of 'home', but as many continually redefined 'homes' premised in the present, for 
instance, as manifesting in the many 'rooms' and 'places' to roam and visit on the Internet. Yet, these post-industrial 'homes' are virtual and comatose.

\section{Closing}

Whether bathed in the glow of the early morning sunrise or evoking fairyland at night through light and neon glow, the spectacle of a striking cityscape continues to generate delight and pleasure. Whether Utopian or dystopian, the urban environment persists in allowing gendered inscription. Cultural theorist Herbert Marcuse (1964:59) seems to have been correct when, at the inception of Post-industrialisation, he maintained that the mythologisation around gender continue to survive in haunting images and positions.

In JG Ballard's novel High-rise (1975:35 - 36), life in a high-rise urban apartment is described as follows: 'A new social type [is] ... being created by the apartment building, a cool, unemotional personality impervious to the psychological pressures of high-rise life, with minimal needs for privacy, who thrive[s] ... like an advanced species of machine in the neutral atmosphere. ... In many ways the high-rise [is] ... a model of all that technology ha[s] ... done to make possible the expression of a truly 'free' psychopathology'.

As expressed in literature and art, a new psychogeography as well as a psychopathology have erupted in the urban context. However, the sexually imaged hold of the city's secrets, disgrace and splendour, seems to linger as an allegorical experience.

\section{Endnotes}

1 This article is an extended version of a paper presented at the Visual Explorations/Culture conference at the University of Pretoria on 10 July 2004.

2 In Romantic literature and art, forests, the sea, mountains and other natural spectacles provided ideal subject matter for both the eighteenth- and nineteenth-century Romantics and the Neo-Romantics of the twentieth century such as Richard Long, Graham Ovenden, Therese Oulton, Sandro Chia and Anselm Kiefer (Papadakis 1988, Mellor 1987, Foster 1962). In many myths and renderings, the spectacle was associated with the sublime, since, as Immanuel Kant postulated, the sublime is often located in phenomena such as the forest 
that overwhelm the rational mind as well as the imagination. Such closed definition as that of Kant has been deconstructed in the postmodern mind set to incorporate different conceptions of the sublime. Deconstruction theorist J acques Derrida (1987) views the sublime as forever shifting, without a locus, indicating that the sublime is solely dependent on perception and viewpoint.

${ }^{3}$ Later, the Marquis de Sade, the Symbolists such as Baudelaire and twentiethcentury French artists such as Magritte, Duchamp and Raoul Hausmann developed this notion explicitly. One of the earliest examples of the humanmachine relationship in twentieth-century visual culture is Fritz Lang's film Metropolis of 1926 in which gender, Utopian and paradisiacal visions are projected onto machine culture and urban life.

${ }^{4}$ William Sharpe teaches in the Department of English at Barnard College, an affiliate of Columbia University.

5 In Biblical times already, visions of the city pointed to the city as text, as a sexual entity and as unreal (Sharpe 1990:2). In Revelation 21 in the Holy Bible, it states that: '[Verse 9] And there came unto me one of the seven angels which had the seven vials full of the seven last plagues, and talked with me, saying, Come hither, I will shew thee the bride, the Lamb's wife. [Verse 10] And he carried me away in the spirit to a great and high mountain, and shewed me that great city, the holy Jerusalem, descending out of heaven from God, [Verse 11] Having the glory of God: and her light was like unto a stone most precious, even like a jasper stone, clear as crystal'.

${ }^{6}$ As found in the myth of Leander swimming stormy seas for every meeting with his love, Hero; also in Orpheus's quest for his dead beloved wife, Eurydice (Mayerson 1971:204 and 272).

${ }^{7}$ In The deconstructive turn, Christopher Norris (1983:91) remarks that the idea of woman is "textually intertwined with a deconstruction of "truth" and its forms of masculine conceptual mastery'. However, according to Jonathan Culler (1983: 166-167): 'Celebrations of woman or the identification of woman with some powerful force or idea - truth as woman, liberty as a woman, the muses as women - identify actual women as marginal. Woman can be a symbol of truth only if she is denied an effective relation to truth, only if she presumes that those seeking truth are me'.

8 Amsterdam Digital City was a project that fostered social transparency and allowed the Internet society access to information via the introduction to Internet basics and Websites.

9 The term 'gaze', and in particular the 'male gaze' as articulated by Laura Mulvey, is a late twentieth-century neologism. Since the middle 1970s, Laura Mulvey has been regarded as one of the most prominent feminist film critics. Her seminal essay, 'Visual pleasure and narrative cinema', that encapsulates her notions on the 'gaze' is reproduced in Film and theory: An anthology (2000), edited by Robert Stam and Toby Miller. Oxford: Blackwell Publishers. 
${ }^{10}$ Even further back, already in the Renaissance, view painting was a popular choice, entitled veduta painting. In particular, architectural view painting was an important class of painting and 'a topographical view depicting a site, a building, a picturesque corner of a city, a panoramic townscape' (Briganti 1970:2) were popular choices of the vedutisti. Although in approach the veduta painters did not distinguish between land- and cityscape, a dualistic ideological worldview of nature versus culture (city) persisted.

${ }^{11}$ A well-known example is Atlantis, an island continent and city recorded in the writings of the Greek philosopher, Plato. The writings of Plato consist of an account of the dialogue that ensued between the scholars of his time. In his Timeaus and Critias, Plato created an imaginary early history for Atlantis, described as a Utopia (Samoilov and Simpson 2000:[sp]). Such Utopia is reflected in Renaissance architecture when cities was conceptualised on possibly the grandest scale in Western history, with immense cathedrals representing European architectural genius.

12 The celebrated author and winner of the 2001 Commonwealth Writers Prize for Eurasia, JG Ballard (Urban Myth 2001:33), remarks: 'Cities are the scar tissue of history, still itching after centuries of deep pathology that erupted, in my own lifetime, into fascism and totalitarian communism'.

13 As in: Heinrich Campendonk, Adam und Eva (1925). Woodcut. Source: Benson, T. O. 2001. Expressionist Utopias: Paradise + Metropolis + Architectural Fantasy. Los Angeles County Museum of Art, Berkeley, and London: University of California Press.

14 As in: Wenzel Hablik, Family housing plan (trans.) (1920). Chalk drawing. Source: Benson, T. O. 2001. Expressionist Utopias.

15 As in: Ludwig Meidner, Strasse im Wilmersdorf (1913). Charcoal drawing. Source: Benson, T. O. 2001. Expressionist Utopias.

${ }^{16}$ As in: George Grosz, Vorstadt (1915 - 1916). Charcoal drawing. Source: Benson, T. O. 2001. Expressionist Utopias.

17 Many dystopian twentieth-century urban renderings and texts link nightmare, disaster and cataclysm with technology. Lewis Mumford, for instance, used the term 'nekropolis' to describe a metropolis that is characterised by looting, famine and disease (Amin and Thrift 2002:8).

18 In 'A Manifesto for cyborgs: Science, technology and socialist feminism in the 1980s' (1991), she defines the cyborg as a 'cybernetic organism, a hybrid of machine and organism, a creature of social reality as well as a creature of fiction' (Haraway 1991: 28).

\section{Sources quoted}


Amin, A. and Thrift, N. 2002. Cities: Reimagining the Urban. London: Polity Press in association with Blackwell Publishers.

Ballard, J. G. 1975. High-Rise. London: Flamingo, HarperCollins.

Ballard, J. G. 2001. Welcome to the Virtual City. In: Urban Myth. Tate, The Art Magazine 24 (Spring): 33.

Baudrillard, J. 1996. The Perfect crime. Translated by Chris Turner. London: Verso.

Briganti, G. 1970. The View Painters of Europe. London: Phaidon Publishers.

Coelewij, L. 2002. Franz Ackermann. In: Franz Ackermann: Seasons in the Sun. Catalogue for the exhibition. Amsterdam: Stedelijk Museum.

Culler, J. 1983. On Deconstruction Theory and Criticism after Structuralism. London: Routledge and Kegan Paul.

Derrida, J. 1987. The Truth in Painting. Translated by Geoff Bennington and Ian McLeod. Chicago and London: University of Chicago Press.

Dreyer, E. 2001. Dystopia and Artifice in Late Twentieth-Century Visual Culture. DLitt et Phil thesis. Pretoria: Unisa.

Foster, R. 1962. The New Romantics: A Reappraisal of the New Criticism. Bloomington: Indiana University Press.

Haraway, D. 1991. A Manifesto for Cyborgs: Science, Technology and Socialist Feminism in the 1980s. First published in the Socialist Review 80, Volume 15, 2 (March - April, 1985). Later published in the Socialist Review Collective, eds., Unfinished Business: 20 Years of Socialist Review (London: Verso 1991). This version reproduced in: Trend, D (ed). 2001. Reading Digital Culture. Massachusetts and Oxford: Blackwell.

Heller, R. 2001. Bridge to Utopia The Brücke as Utopian Experiment. In Benson, T. O. (ed). Expressionist Utopias Paradise + Metropolis + Architectural Fantasy. Los Angeles County Museum of Art, Berkeley, and London University of California Press.

Heim, M. 2001. The Erotic Ontology of Cyberspace. In Trend, D (ed). 2001. Reading Digital Culture. Massachusetts and Oxford: Blackwell.

Hobbs, S. [Sa]. Artist's statement on On Interesting Spaces (1997). [O] Available: http://www.artthrob.co.za/dec98/artbio.htm. Accessed on 12 August 2004.

Huyssen, A. 1995. Twilight Memories: Marking Time in a Culture of Amnesia. New York and London: Routledge.

Mayerson, P. 1971. Classical Mythology in Literature, Art, and Music. New York: John Wiley.

Mellor, D. (ed). 1987. A Paradise Lost: The Neo-Romantic Imagination in Britain 1935 - 55. London: Lund Humphries in association with the Barbican Art Gallery.

Morley, D. and Robins, K. 1995. Spaces of Identity. Global Media, Electronic Landscapes and Cultural Boundaries. London and New York: Routledge.

Papadakis, A. C. (ed). 1988. The New Romantics. Art and Design 4 (11/12). London: Academy. New York: St. Martin's Press.

Samoilov, A. and Simpson, E. 2000. Plato's Atlantis. [O] Available: http://www. auburn.edu/ downejm/sp/epsaas/epsaasPlato. html. Accessed on 2 July 2004. 
Sharpe, W. 1990. Unreal Cities Urban Figuration in Wordsworth, Baudelaire, Whitman, Eliot, and Williams. Baltimore and London: The Johns Hopkins University Press.

Stephen Hobbs. Artist's bio. Artthrob: Contemporary art in South Africa.

[O] Available: http://www.artthrob.co.za/dec98/artbio.htm.

Accessed on 12 August 2004.

Swift, J. 1726. Gulliver's Travels. This edition 1959. Edited by Herbert Davis. Introduction by Harold Williams. Oxford: Basil Blackwell.

Trend, D. (ed). 2001. Reading Digital Culture. Massachusetts and Oxford: Blackwell.

Urban Myth. 2001. Tate, The Art Magazine 24 (Spring).

Williamson, S. and J amal, A. 1996. Art in South Africa The Future Present. Cape Town and J ohannesburg: David Philip.

Woesler de Panafieu, C. 1984. Automata - A Masculine Utopia. In Mendelsohn, E. and Nowotny, H. (eds). 1984. Nineteen Eighty-Four Science between Utopia and Dystopia. Dordrecht/Boston/Lancaster: D. Reidel.

\section{List of figures}

Figure 1

Michael Maier, Emblema XLII from the Atalanta Fugiens (1617). Etching. Source: [O] Available: http://www.levity.com/alchemy/atl41Figure 2

45.html(accessed: 16 J une 2004). Courtesy of Adam McLean.

Franz Ackermann, Untitled (Mental map: The secret story of Amsterdam) (2002). Pencil on paper, $70 \times 100 \mathrm{~cm}$. Courtesy: neugerriemschneider, Berlin.

Figure 3

Walter van der Cruijsen, Screen shot of Amsterdam Digital City (1994). Web page production. Source: [O] Available:

http://www.thing.desk.nl/wvdc/HTML/dds.html (accessed: 2 December

Figure 4 2004). Courtesy of the artist.

Cristina I glesias, Untitled (2001). Concrete, installation. Source: [O] Available: http://www. renaissancesociety.org/show/iglesias/iglesias. pdffigures

(accessed: 16 June 2004). Courtesy: Whitechapel Gallery, London.

Figure 5

Francis Alÿs, Francis Alÿs and the collector (1991) Photo: Ian Dryden. Source:

[O] Available: http://images.google.com/images?hl=en\&lr=\&ie=UTF-

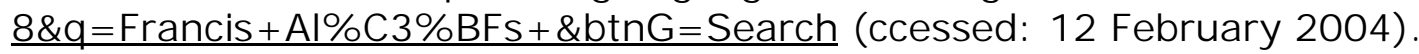

Figure 6

Vanessa Beecroft, Video still from the performance, Show (April 23, 1998).

Produced by Yvonne Force Inc. at the Solomon R. Guggenheim Museum, New York. Fugiflex print, 42 × 52 inches. Photograph: Mario Sorrenti. Source: [O] Available:

http://www.yvonneforceinc.com/yfinew/beecroft.htm (accessed: 25

October 2001). Courtesy of Yvonne Force. 
Figure 7

Stephen Hobbs, Dusk till Dusk (1997). Still from the video. Source: [0] Available: http://www.artthrob.co.za/dec98/artbio.htm (accessed: 12 August 2004). Courtesy of the artist.

Figure 8

Stephen Hobbs, On Interesting Spaces (1997). Still from the video. Source: [0] Available: http://www.artthrob.co.za/dec98/artbio.htm (accessed: 12 August 2004). Courtesy of the artist.

Figure 9

Tracy Payne, Coastal resort (1996). Pastel on paper, $115 \times 84,5 \mathrm{~cm}$. Source: Williamson, S. and Jamal, A. 1996. Art in South Africa The Future Present. Cape Town and J ohannesburg: David Philip: 116. Courtesy of the artist. 